\title{
Интеллектуальные тормозные колодки с встроенными адресными волоконными брэгговскими решетками
}

\author{
О.Г. Морозов, А.Ж. Сахабутдинов, И.И. Нуреев, А.А. Кузнецов, В.И. Артемьев \\ Казанский национальный исследовательский технический университет им. А.Н. Туполева-КАИ \\ *E-mail: vadimartemev93@mail.ru
}

DOI:10.31868/RFL2018.204-205

Распространение «интеллектуальной» концепции во многих областях транспортного машиностроения приводит к увеличению спроса на компоненты с более высокой надежностью. Для удовлетворения постоянно растущего спроса на новые и более надежные компоненты все чаще требуется контролировать их характеристики в режиме реального времени с использованием для сравнения как модельно, так и физически полученных априори экспериментальных данных об их «правильной» работе. Последнее помогает идентифицировать потенциальные режимы отказа и, таким образом, обеспечивает надежность указанных компонент и транспортных средств в целом, как того требуют производители или конечные пользователи.

К таким компонентам относятся антиблокировочная система (АБС) тормозов автомобиля и тормозные колодки (ТК), как их составная часть. Учитывая, что тормозная система - это основа безопасной эксплуатации автомобиля, исследования по данной тематике являются актуальными [1-3]. Основные существующие методы контроля тормозных систем - визуальный и анализа поведения автомобиля при торможении. К основным дефектам визуально можно отнести металлизацию, замасливание и загрязнение колодок; изменения цвета, вызванное перегревом; наличие трещин, сколов, разрушений; формирование клинообразного профиля или отсутствие износа при эксплуатации при дефектной работе суппорта. Эффективная работа антиблокировочной системы тормозов автомобиля повышает вероятность сохранения управляемости автомобиля в условиях резкого торможения. Своевременное диагностирование и профилактика неисправностей АБС обеспечивает активную безопасность транспортного средства. При этом анализ функционирования системы должен проводиться в первую очередь с помощью бортовой диагностики [4].

Если для многоточечных, многопараметрических измерений в целях диагностики АБС и ТК, использовать существующие электронные средства измерений, это приведет к резкому увеличению, дополнительно к функциональным, измерительных каналов, что уменьшит общую надежность транспортных средств. Кроме того, следует учитывать ограниченность пространства и необходимость подавать кабели к вращающемуся узлу - колесу, а также проблемы, которые могут быть вызваны электромагнитными помехами и короткими замыканиями. Изза относительно большого размера традиционных датчиков результирующая сенсорная система может потенциально занять пространство больше, чем сам тормозной привод.

Таким образом, необходимы новые решения вышеупомянутых проблем путем замены традиционных методов контроля и датчиков на волоконнооптические, использующие интегрированные, квазираспределенные, адресные технологии для мониторинга АБС и ТК в режиме реального времени. Такой под- 
ход в полной мере использует малые размеры оптических датчиков, их иммунитет к электромагнитным помехам, что критически важно для данной задачи.

Эта работа основывается на предыдущих работах авторов [5-8], выполненных с целью создания многопараметрической сенсорной системы, которая позволяет в реальном масштабе времени контролировать износ и температуру угольных щеток электрических машин, дополнительно получая информацию о скорости вращения и состоянии ее ротора. Решение было найдено без использования массива специально расположенных датчиков на основе волоконных брэгговских решеток (ВБР). Для измерений использовалась одна адресная для каждой щетки ВБР, экономически эффективно устраняя необходимость в индивидуальном датчике для каждого параметра и, следовательно, значительно уменьшая сложность мониторинга состояния электрической машины без потерь по функциональности. Адресная ВБР - решетка, в структуру которой введены два симметричных фазовых $\pi$-сдвига, частотный разнос между которыми определяет адрес ВБР, обработка информации с которой ведется на упомянутой индивидуальной разностной частоте, лежащей в радиодиапазоне [9-10]. Износ щетки, параметры вращения ротора, его качественное состояние определялись по амплитудным и частотным параметрам огибающей биений между составляющими, определяемыми положением окон прозрачности ВБР, в различных областях радиочастотного спектра; температура - по положению средней частоты решетки относительно склона трапецеидального прямоугольного фильтра, также определяемой по коэффициенту модуляции огибающей биений, для которого определен динамический диапазон измерений.

Разработанная, подобным образом сенсорная система «все-в-одном», была протестирована для контроля состояния ТК автомобиля: их перегрева или недогрева при проскальзывании, износа и его неравномерностей, контроля давления суппорта, которые особенно важны для обеспечения безопасности движения. Таким образом, многопараметрический выход по одному волокну из встроенной в ТК одной или нескольких параллельных адресных ВБР, позволяет создать сенсорную систему, которая может использоваться для эффективного мониторинга и сигнализации начального отказа. Ключевая особенность системы состоит в том, что ее можно использовать, когда двигатель работает из-за оптической природы считываемого датчика, таким образом, что не мешает работе двигателя.

Принципы работы и дизайн макета датчика обсуждаются в докладе, затем приводятся результаты серии испытаний датчиков, встроенных в ТК, после чего делаются выводы о производительности и возможностях новой системы интеллектуальных тормозных колодок с встроенными адресными ВБР с учетом возможности контроля АБС в целом.

Работа выполнена при финансовой поддержке Министерства образования и науки Российской Федерации в рамках государственного задания КНИТУ-КАИ №8.6872.2017/8.9.

\section{Литература}

[1] М.М. Зайцева, А.В. Напханюк, Инженерный вестник Дона, №1 (2018)

[2] М.М. Зайцева, А.Д. Кирчев, Инженерный вестник Дона, №1 (2018)

[3] М.М. Зайцева, А.К. Новикова и др., Инженерный вестник Дона, №2 (2018)

[4] Д.З. Евсеев, М.М. Зайцева и др., Инженерный вестник Дона, №2 (2018)

[5] А.А. Кузнецов, В.И. Артемьев и др., Инженерный вестник Дона, №1 (2016)

[6] Р.Ш. Мисбахов, В.А. Иваненко и др., Фотон-экспресс, №6 (2017)

[7] О.Г. Морозов, И.И. Нуреев и др., Фотон-экспресс, №6 (2015)

[8] Рус.Ш. Мисбахов, Рин.Ш. Мисбахов и др., Инженерный вестник Дона, №3 (2017)

[9] К.В. Маскевич, Р.Ш. Мисбахов и др., Фотон-экспресс, №4 (2018) 